\title{
ETHICS IN COMMERCIAL QUALITATIVE RESEARCH - ANYBODY SEEN THEM? ON THE ETHICAL DILEMMAS OF RESEARCHERS INVOLVED IN COMMISSIONED RESEARCH
}

\begin{abstract}
The article reflects on problems of an ethical nature faced by researchers utilising qualitative methodology in privately funded research - social and political opinion polls, or market research projects. The commissioning entity is at the same time an evaluator of the research project, its recipient, and a client, which may affect the research process.

Utilising source literature, in the article I will present analyses carried out for a project concerning the patterns of professional careers of researchers who work in private research agencies (market and opinion polling researchers) which was the basis for my $\mathrm{PhD}$ thesis and examples from my own long-standing research practice. I hope this article represents a valuable contribution to a further discussion on this topic.

Keywords: research ethics, qualitative research, commissioned research, privately funded research, commercial research, market research, marketing research.
\end{abstract}

\section{INTRODUCTION}

In social research, alongside analytical, methodological, and conceptual dilemmas present in every level of the research process - from designing the study, through gathering and analysing the data, to writing reports - we face another

Dr, e-mail: katarzyna.archanowicz@gmail.com; https://orcid.org/0000-0002-9888-2667 
equally important issue, namely that of ethics and protecting research participants. Increasing sensitivity to issues of an ethical nature results from two major factors: First, the academic field has become more and more sensitive to humanistic values, which in itself is a result of the post-positivist revolution. Second, there is a growing popularity of social research and broader application of social studies. This is also where the greatest controversy lies, sparking considerable discussion and tensions because at least partially it seems to run counter to research reliability and validity [Kvale 2004: 131; Dudkiewicz 2016: 138; Niedbalski 2016: 36; Ślęzak 2016: 105; Świątek-Młynarska 2019: 205]. In particular this applies to studies of qualitative nature - and not only to academic projects, but to commissioned research as well.

The goal of this article is to discuss ethical dilemmas in the context of commercial qualitative research - market and marketing research ${ }^{1}$. Such studies are quite numerous both in Poland and worldwide: According to the Polish Society of Market and Opinion Researchers, in 2018 alone research institutes conducted qualitative research engaging around 100,000 people in Poland, using in particular in-depth interviews and focus group interviews [Chojnowski 2019: 29] ${ }^{2}$. It is difficult, however, to find any literature on the subject of an actual data gathering and analysis, a so-called research "kitchen" of such studies or ethical dilemmas faced by researchers.

This article is based on an analysis of 22 unstructured interviews with a standardised list of searched information [Przybyłowska 1978: 56 $6^{3}$, conducted with experienced researchers functioning in the reality of qualitative social and market research, and with former commercial qualitative researchers. The interviews were conducted for the purpose of my $\mathrm{PhD}$ dissertation defended in 2017 [Archanowicz-Kudelska 2017]. The idea to create a sociological portrait of such researchers, to understand their worldview and career choices, and explain the processes and mechanisms behind specific observed behavioural schemes

1 In this article I use the terms "commercial research", "commissioned research" and "market research and opinion polls" as well as "marketing research" in the sense of research conducted by research institutions on the order of external entities. In this sense I use these terms as synonyms, although I am well aware that not all commissioned research is marketing research.

2 Over that time, those institutions surveyed in Poland nearly 12.2 million people in total, primarily utilising quantitative methods ( 6.4 million were surveyed by means of the CAWI method) [Chojnowski 2019: 29].

In her own article Przybyłowska recalls the original English term used for this technique, i.e. non-scheduled standardised interview, which she translates into Polish as "wywiad swobodny ze standaryzowaną listą poszukiwanych informacji" [Przybyłowska 1975: 458] - footnote form the editors of the volume. 
originated from my own experience of working in such research institutes. Over more than a decade of my professional career, I have worked in four different institutes, first as an ordinary researcher and a moderator, and then as a coordinator of a research team dealing with qualitative research. Such work involves not only numerous projects and hundreds of hours of moderating individual and group interviews; it also involves hours of observations and conversations with co-workers, contractors and clients about specific projects, situations, and the nature of the profession as such. I am aware that all of that had an impact on both the interviews themselves, as well as their analyses. Although personally I have always striven for objectivity to the extent I could, and I have tried to distance myself from my own views, I believe that stating one's engaged position in the reality which we study is simply a matter of intellectual honesty. Following Juliet Corbin, I take the position that "we do not separate who we are as persons from the research and analysis that we do" [Corbin 2009: 40].

Therefore, this paper contains references to my $\mathrm{PhD}$ thesis, direct statements from research participants gathered in the course of interviews, as well as my personal observations collected throughout my longstanding research practice in commercial research.

\section{ETHICS IN QUALITATIVE RESEARCH}

The current literature primarily focuses on the basic principles which researchers should adhere to in order to ensure high ethical standards of the social research they conduct [Babbie 2006: 515-519; Czajkowska, Hinc 2005: 247]. Such an approach takes into consideration that specific relationship which exists between a researcher and research subjects, with an emphasis on the need to subjectify the latter and the difference (and not only a lexical one at that) between studies "with a person" - a subject, and studies "on a person" - an object [Urbaniak-Zając, Kos 2013: 77]. Research participants should be treated not only as "sources of data" but with the due respect they deserve [Charmaz 2009: 30; Ślęzak 2016: 103], and not all means should be used in pursuit of the goal of obtaining valid data. The recommendation is therefore to clearly inform the participants at all times of the benefits and burdens which a research process entails so that they can provide their informed consent; to respect their privacy and confidentiality of the data we collect from them, and to prevent any omission or manipulation in gathering and analysing the research material.

Because of a direct and often even intimate contact between the researcher and the subject, qualitative research projects occupy a prominent place in the discus- 
sion of research ethics. Reliable and in-depth qualitative research, as repeatedly emphasised in the literature, is only possible when the subject trusts the researcher and gives them access to their own private and often hidden experiences [Hammersley, Atkinson 2000: 271; Konecki 2000: 172; Ślęzak 2016: 102]. However, many field researchers who have direct contact with research participants need to address a vital question: Does the goal of conducting a cognitively interesting project which has applicable value fully legitimise gaining and using such trust or not in every case? [Ślęzak 2018: 143].

In the case of commercial research, it can be a matter of even greater dispute because, how a research participant is being treated does not depend exclusively on the researcher, but rather it is written into a certain industry scheme over which the researcher does not have full control, and the very goal of the research initiating the project is imposed from above.

\section{THE NATURE OF SOCIAL RESEARCH AND CODES OF RESEARCH ETHICS}

Due to the nature of social research in the commercial context - opinion polling, market research and marketing research, and due to systemic solutions applied mindlessly by the commercial research industry, issues such as protecting research participants and emphasising their subjectivity become problematic. This is so because this kind of research is, in fact, a hybrid of a sort - on the one hand, it is still research of an academic etiology, but on the other it is, after all, a commercial service subject to the same market rules (such as the law of supply and demand) as other services.

In commercial research we can distinguish several parties involved in a research project. They have different goals, needs and negotiation power; they are also different in terms of awareness and ethical sensitivity. These parties are: researchers (both individual researchers and institutions responsible for the research) and research participants, but also (and this is the feature distinguishing this kind of research from purely academic studies) clients - persons and companies who order and sponsor a given study. The goal of commercial studies is to provide an answer to specific questions, needs, and problems the clients have [cf. Dudkiewicz 2016: 139]. As such, they can serve the purpose of surveying the market, the political or social landscape, ongoing monitoring of current operations or the control and evaluation of concluded activities. Therefore, the researcher or the team of researchers who work on commercial projects have very limited research 
freedom - they do not choose the research problem and research questions, and sometimes even the methodology or tools they would use is beyond their control. They act merely as service providers whose task is to best meet the expectations of the ordering and sponsoring party - the one who decides what shall be studied and quite frequently also how. The relationship between the client and researcher is also unequal [Lisek-Michalska 2013: 176] - clients are the source of income for research agencies, they evaluate the researcher, the study itself and the agency, and make the ultimate decision about whether they (and the financial resources at their disposal) will continue to cooperate with a given research institution or not. In the ongoing price war between competing research agencies [Staszyńska 2013: 124], clients are fully aware of the advantage they have, which as a result makes the relationship anything but symmetrical and may contribute to numerous and serious moral dilemmas of researchers who conduct commissioned research. Only some of them can afford to, for example, refuse to work on a given research problem or undertake a project commissioned by a particular client or company. Others, in turn, may face a need to bend their ethical or methodological principles or even go against them so that they or the research agency which employs them can continue their business activity - be awarded a contract, conduct a particular study or retain a client and a research budget.

The sales department is delighted because they sold the study. They already have done their job and they are happy. And I receive something that is either utterly impossible to do - because it's non-methodological, or can't be done within a given budget, as the costs and efforts exceed it. If I say that it's just impossible, I hear: "she should be happy that she has a study to do, and here she's picky again”. So I try to figure out how to conduct the research to keep everybody happy... [Project manager in a research team]

Our client wanted us to talk to two-year-olds. I am telling her that two-year-olds won't say anything because they are too young. She says: 'Then three-year-olds. You don't want to do it either? Someone else will do it then!' And in the end we did it... [Former leader of a qualitative research team $]^{4}$

The ethical dilemmas of researchers are further complicated by the fact that commercial research and analyses are not done for public benefit, but become the sole property of the entities who order them. Unlike academic social research which is usually conducted for the public use, commissioned research results in a so-called "hidden" knowledge, private and accessible only to the specific client who paid for it [Poleszczuk 2009: 12] and who makes use of it for their own

4 All quotes come from interviews which I conducted with experienced market researchers for the purposes of my PhD thesis mentioned in the introduction [Archanowicz-Kudelska 2017]. 
purposes. Upon the completion of the project, the researcher has no control over how and for what purpose the study conducted will be used.

Theoretically, in modern marketing research ethical issues play an important role. This fact is grounded and elaborated on in catalogues of good practices - codes of ethics. Such codes include principles which all researchers should adhere to when conducting marketing research in order to ensure the ethos and reputation of market research. Among them, the most important code, binding in Poland (and over 130 other countries) is the ICC/ESOMAR International code on market, opinion and social research and data analytics ${ }^{5}$. One of the fundamental principles of the Code, which form the reference frames for the interpretation and application of particular clauses is the following: "Researchers must always behave ethically and not do anything that might harm a data subject or damage the reputation of market, opinion and social research". [ESOMAR: 10/c.3] The new version of the Code, updated in 2016, consists of 12 clauses which define researchers' responsibilities towards: data subjects (clauses 1-6), clients (clause 7), the general public (clause 8), and the research profession itself (clauses 9-12).

When in doubt, commercial researchers may also refer to other codes of academic ethics, such as: The sociologist's code of ethics [Polish Sociological Association 2012], The code of professional ethics of [Polish Psychological Association 1991], anthropological: Ethical guidelines for good research practice [Association of Social Anthropologists of the UK and the Commonwealth 2011], Statement on ethics: Principles of professional responsibility [American Anthropological Association 2012] or The code of academic ethics [2012] which they most likely became familiar with in the course of their academic studies ${ }^{6}$.

Every code of ethics, despite written rules and formal conditions, is only discretionary - as a social contract, it serves as a guideline and does not constitute a binding law or a set of binding principles [Niedbalski 2016: 37]. Moreover, knowledge of such codes and referring to them in daily research practice seems to be quite rare and superficial at best [Marciniak 2014: 284]. None of the research companies known to me held any training events or workshops, neither were

5 The first ESOMAR code was published in 1948 and was followed by numerous other codes developed by national organisations and the International Chamber of Commerce (ICC). In 1977, ICC and ESOMAR agreed on and published a joint document. The ICC/ESOMAR code was later updated in 1986, 1994, 2007 and most recently in 2016.

6 Commercial researchers usually have a degree in social sciences - sociology or psychology, although some of them have some other related degree [Sielicki, Ciemniewski 2013: 5]. It is also worth noting that how particular ethical issues are approached is largely discipline-specific [cf. Surmiak 2016: 131]. 
their qualitative researchers encouraged in any way to make use of the codes in their daily practice (although, of course, each of those companies pride themselves in following the ESOMAR code).

\section{THE NATURE OF QUALITATIVE COMMISSIONED RESEARCH - THE MODERATOR, THE RESPONDENT, THE RECRUITER AND THE CLIENT}

Commercial market research, which flourished in post-transformation Poland [Staszyńska 2013: 23], has become subject to various modifications and changes over time [Maison 2015: 9]. Such changes have impacted research tools and techniques, and also affected the time and place of where studies may be conducted, but are yet to affect the attitude to research participants. Research participants are still perceived rather within the positivist paradigm (although the concept of a paradigm and theoretical frame is not used in this case). What is significant is how we commonly refer to our subjects in commercial research: We often speak of "respondents". This term may evoke particular connotations - some researchers point out that as a "respondent" derives from the verb "to respond", it may imply the asymmetry of an interrogation. The role of the "respondent-interrogated" is to provide a possibly detailed and coherent account on a given subject. In return, though, they themselves will not learn anything from the higher-ranked "researcher-investigator". They will never know what the researcher thinks, or even what emotions their answers evoked because a good practice in commercial research is to exercise restraint and "academic neutrality" [Maison 2010: 241]. The researchers are not supposed to show the participants how their responses affect them (in this context usually referred to as a "moderator"). What further aggravates this situation is the technical aspect of commercial research - whenever possible, such studies take place in a so-called focus studio [Maison 2010: 141; Lisek-Michalska 2013: 114]. Such a room is equipped with a one-way mirror behind which other people often watch the interview in real time. Also, to those unfamiliar with the research industry, recording equipment - video cameras and microphones - may give the impression of an interrogation room.

Below I describe a process of participation in qualitative market research from the perspective of a respondent. The goal is to show that the procedures which companies have used for years, objectify participants to an extent which is neither necessary, nor desired in order to conduct an efficient but reliable field study. Moderators, as those who are in direct contact with subjects, and who are the recipients of their emotions, face various ethical dilemmas which they need 
to address for the sake of the participant and the methodological correctness of the entire process, but also for the sake of loyalty to their employer and client.

In such studies the research sample is a targeted sample, therefore participants should meet very specific, sometimes quite strict recruitment criteria. As such criteria are imposed by the client who orders the research, sometimes they are highly restrictive and difficult to meet - for example, a client looks for a person of a particular age, gender or income at a particular point in their life, or subjects who use particular products. The task of recruiters ${ }^{7}$ is to find people who meet the criteria of a given project. If such prospective participants agree to take part in a study, they are invited to an interview at a particular location and time. Because recruitment deadlines are typically quite tight (around one week), sometimes the selection criteria are loosened and invitations are given to people who meet them only partially. In some cases participants are not aware of this discrepancy, in others they are. In the latter case, sometimes they make a deal with the recruiter - they claim to meet the criteria and in order to do so they either purposefully hide or knowingly distort certain information about themselves and their situation ${ }^{8}$. As research companies are aware of this problem, upon arrival, immediately prior to the interview, participants are once again subject to tests and verification of whether they match the respondent profile or not. All participants fill in another questionnaire, this time on their own. This is a so-called "screener". Prospective participants answer a number of questions about their socio-demographic profile and their use of specific products or shopping habits. At this time their appearance and behaviour are also examined in order to eliminate people who in the view of the interviewer, client, or other employees of the research company are not a good fit for the interview or group discussion (for example, because their appearance or behaviour is deemed unusual, or they are recognised as "professional respondents"'). All of this takes place under time pressure, often in a waiting room or

7 Larger research institutes, usually located in Warsaw, have so-called "coordination centres" scattered throughout the country. When a centre receives an order to conduct a research in their area, its task - or more appropriately the task of the recruiters it cooperates with - is to find suitable respondents in accordance with the specified criteria and ensure timely preparation of the location where the study will take place. The researcher is usually an employee of a given institute who will show up in that particular location only for the time of the actual study.

8 Recruiters usually receive payment for every recruited person who shows up at a specified time and is classified as meeting the recruitment criteria.

9 A "professional/trained/fake" respondent is a person who considers marketing research as a source of income and knowingly provides false information about themselves, so as to always meet the expected criteria. Once recruited, they often provide answers they consider fitting the profile which that particular researcher is looking for. 
in a hall. Prospective participants can easily figure out that their knowledge and views are verified several times; they are expected to provide specific answers and inconsistencies will not go unnoticed. When coordinators or the researcher check the "screeners", those who are found unsuitable for the research are sent away and do not participate in the subsequent part of the research, receiving only a symbolic remuneration for their time. This procedure is immanently written into the project cycle because such "over-recruitment" is common: Invitations are issued to more people than needed for a particular study. This reduces the risk of having to cancel the research if due to unforeseen circumstances some participants fail to show up or do not meet the recruitment criteria. If all of the invited people are found to be "suitable" respondents, some of them are sent away so that the number of subjects does not exceed the contracted number of participants ${ }^{10}$. Usually it is not until invitation to the interview room that selected participants meet the moderator.

It is significant that even the initial selection criteria and the recruitment process itself, even before the actual study with participants begins, may be unclear and stressful to respondents. Although the main goal of the research is to encourage participants to cooperate and give them an opportunity to talk freely and openly, the result may often be quite the opposite.

Usually it is only in the interview room where the research participants selected for further stages of the project are introduced to the researcher, and in the case of group projects, to other participants. The moderator has a limited time for the entire meeting (most commonly such interviews last around two hours); however, the primary goal is to make a connection with the subject or the group of participants, ease their stress, and remind them or explain to them the rules. This is also the time to build trust (often already challenged by the recruitment procedure) between the researcher and the subject, which is key to the following parts of the research process. However, due to a packed discussion script, this part is usually extremely short - rarely exceeding five minutes (10-15 minutes in a group study when all participants introduce themselves). This is so because clients who are not aware of the importance of this element may try to pressure the researchers to shorten this part as much as possible, as in their minds it lacks any "productive" value.

From the very beginning of the interview, the moderator may also feel uncomfortable. This is often the case when he or she is aware that some of the respondents, even those who have successfully completed the entire recruitment

10 The number of interview participants is agreed upon with the client. The standard is 7-8 participants, although recently the number has decreased to 4-6. 
process, may not meet the strict recruitment criteria or for various other reasons should not participate in the study.

What is therefore ethical? To remain loyal to the client, point out the discrepancies (which may lead to cancelling the interview or focus group) and send the participant away, letting them know that they are not "suitable", or rather to remain loyal to the employer (the research institute) and proceed with the interview in such a way so as to conceal the inaccuracies or at least not make them distinct? The institute has already invested time and resources in a given project. If the interview is cancelled, all will be lost, which in turn translates into lower profit. The researcher wants to complete the study (after all, they are accountable for the commercial viability of the project ${ }^{11}$ ) and they know that in reality some of the recruitment criteria are not as vital as the ordering party claims them to be.

Sometimes a client wants a respondent who used to drink nothing but $\mathrm{X}$ up to three months ago, and now drinks only Y. Because the results of a quantitative study showed a decrease in the sales of X. Find me such a person! You can't find them? You're not looking enough! So they say they found someone, and then I talk to that person and pretend I believe him. [Director in a research boutique, for 15 years worked in international research companies]

On the basis of my own experience and the interviews which I conducted over the years I can conclude that researchers deal with this problem in various ways, judging every situation on a case-by-case basis. They often choose a short-term solution: They continue the interview (and protect the research participants as well as the "commercial viability of the project"), and then, if they deem that particular participant not "suitable enough" because his or her answers might disrupt the reliability and validity of the analysis, they might simply not take them into account ${ }^{12}$.

During the interview itself, the researcher faces further dilemmas which need to be addressed on an ongoing basis. Regardless of the topic of the discussion (which may seem most neutral: shopping habits, evaluating a commercial or

11 The ultimate viability of the project usually affects the remuneration of the researcher himself, who often is paid a commission rate.

12 In my opinion, any respondent regardless of his or her features or behaviour, once invited to a discussion shall have the right to participate. The only two exceptions are: 1) when the subject can pose a danger to the researcher or other people and his behaviour makes it impossible to continue the study (eg is under the influence of psychoactive substances), 2) when he or she is a professional respondent. Such instances should be noticed and eliminated at the final selection stage before the interview begins. In the case it did not happen, especially in a focus group interview, the researcher should always thoroughly consider such a radical decision as removing a group member, and at the same time be aware how it will affect other participants. 
talking about favourite leisure activities), also commercial research may lead participants to refer to their own personal experience, verbalising such experiences and life choices, which may result in an in-depth reflection and auto-analysis of their own habits, choices, behaviours or motives (sometimes even for the first time in their lives). Naturally, commercial research, or any other kind of qualitative research for that matter, is not a form of therapy; researchers are neither qualified nor interested in therapy. The participants, however, may not always be fully aware of this distinction and may expect some sort of help or assistance with their problems from the researcher; some meetings may therefore become quasi-therapeutic in nature [Dickson-Swift et al. 2007: 306; Konecki 2000: 173; Ślęzak 2016: 103]. The point where the researchers should restrain themselves from going more in-depth into the participants' worlds, may and indeed do pose ethical dilemmas. Balancing the participant's well-being, researcher's own role and abilities and also a research goal might be quite challenging.

The researchers are responsible for supervising the research process and they may also expect - seeing the entire situation from a meta-level - that, for example, participants may later regret their honesty and openness during an interview, or feel exploited (especially given the fact that in the course of an interview participants tend to forget that they are being watched and recorded).

I was carrying out a project on the link between love and food. Very in-depth, lasting a few hours, interviews about attitudes. People began to understand, verbalised some things. They even cried, experienced catharsis - and then I was leaving them. I don't know if I had any right to pull that string in them. The better, the more in-depth my work was, the more I wondered whether I had a moral right to do so. Sort of like psychotherapy but not for their own benefit... And then the client makes an advert about a broth... [Former qualitative researcher who after over a decade of working in commercial research changed her profession]

The aforementioned dilemmas are well-known to qualitative researchers [Kvale 2010: 123; Ślęzak 2016: 104, 2018: 156], but in the case of commissioned research, they are further augmented by the fact that the researcher and participant are not the only ones directly involved in the interview process. As I noted above, a commercial interview is usually followed by third parties (commissioners), who observe it through a one-way mirror (there is a special room for observers, commonly known as a viewing facility /in Polish - "podglądownia"/) [cf. Lisek-Michalska 2014: 131]. Usually they are highly interested in the course of the discussion or interview they are watching; however, they do not always have a suitable theoretical or methodological background. The atmosphere in a viewing 
facility is sometimes quite relaxed, even "club-like" - it is dark ${ }^{13}$, clients sit on comfortable couches and armchairs, enjoying snacks and beverages, and sometimes even alcohol. The goal is to make the observers feel relaxed and at ease, which is supposed to translate into a positive evaluation of the research agency and the research project itself. However, sometimes it also results in irrelevant comments on the looks or behaviours of the participants. The observers are often merely curious and watch with great interest how participants become increasingly more open and share intimate details of their lives. Therefore, a researcher who manages to conduct an interview in such a way may be rewarded not only with the internal satisfaction and joy of achieving an in-depth conversation, but also may expect positive evaluation from the client who ordered the research.

Participants are always informed that they will be recorded and observed. They should be made aware of this at the recruitment stage, but sometimes the recruiter "forgets" to inform the prospective subjects and the first person to mention this is the researcher at the beginning of the meeting. Considering how much the respondent has already invested by then (taking the time to show up and complete the entire recruitment process), it may be interpreted not as much as a request for informed consent, but as a mere statement of fact (which may be perceived as manipulation). In theory, research subjects have the right to refuse further participation at any time, terminate the interview, and leave [Kvale 2010: 64] and if they did so no one would stop them; however, in reality such instances are extremely rare.

I saw respondents being quite surprised by what they encountered... (...). Even though they gave their written consent. And because of that consent, they always stayed until the very end, even if they didn't like it. It never happened to me during an interview or a group discussion that someone just stood up and walked out. I think people sense it's not a right thing to do, they are afraid. [A former qualitative researcher]

Moreover, researchers usually do not inform participants about the number of observers or about the real reason and purpose of them watching the interview. For many years I would often hear and say phrases like, "Behind this one-way mirror sits my friend who is taking notes", even though in reality there were several representatives of our client, the advertising agency whose works were the subject of our research, and a simultaneous interpreter ${ }^{14}$.

13 Naturally the main reason for dimming the lights in a viewing facility is the semi-transparency of the one-way mirror. If the room was bright, the participants would see the observers.

14 It is also doubtful that respondents would always understand what exactly the term "one-way mirror" means; however, it is often not explained. 
As mentioned above, those who observe the interview, tend to judge the behaviours and answers of respondents, even though sometimes they lack an adequate methodological background. Experienced researchers everyday have to deal with respondents who are tired, bored, are not self-confident, not creative or subject to cognitive distortions, and most of all are irrational [cf. Maison 2015: 15]. To inexperienced observers all that may come as a surprise. They may begin to doubt whether a given person is a "good fit" for the study. This becomes most distinct and plays a significant role when the client holds views on subjects being discussed in an interview that are different to those of the participants. Such situations are not uncommon because clients who observe an interview, where participants evaluate "their" brand, product or service and discuss the concepts and ideas which clients have developed and worked on diligently, bring their own views, motivations and attributions (in spite of declarations of impartiality), which they may not even be aware of. Observers may then experience strong tension, the reduction of which may take place by means of depreciating participants or the researcher during the interview - in a "kill the messenger of bad news" mode. This is far more noticeable in the case of qualitative research as research recipients have a lower understanding of the qualitative methodology and their intuitional perception of it is often reduced to little more than a "word against word", in contrast to quantitative studies, which generally enjoy greater acceptance because they are based on statistical analysis.

The client is watching a group and analyses what he sees. As long as everything is going well, everyone is happy. Worse, though, if the results are different from the expectations; then we have a problem and nitpicking. [Director in a research boutique]

Sometimes I feel like the bearer of bad news who is about to get stoned to death because some product which was supposed to be spectacular has not been received all that well by groups. [Qualitative researcher in a small Polish research company]

Such perception of the interview may become clear to moderators while the discussion is still on-going. Sometimes they may be called out of the focus studio to receive suggestions or even requests from the client who wants specific questions to be asked or conversely, wishes for certain respondents or subjects to be skipped in the discussion. In extreme cases the client may even demand to finish the study ahead of time if it is perceived that the respondents are not suitable (for example, not engaged or not intelligent enough) and fail to meet expectations. Aside from how it affects the researcher, it also has an impact on the entire research situation and participants who to a greater or lesser extent realise that something "is not right". Extreme examples of demanding to cancel 
the interview are fairly rare; however, contacting the moderator in the course of a discussion is very common. Some research agencies even encourage observers to do so, equipping the viewing facility with a direct connection into the focus room so that the moderator can follow suggestions and comments sent by clients in real time - displayed on a special screen, theoretically invisible to the respondents.

Sometimes it's just beyond crazy. I can see that there is a huge row happening - as according to the client the research isn't going well, participants aren't good enough, they were poorly recruited, they don't say what they "should" say, the moderator is called out only to hear that everything is awful but he has to be nice, so just nods, assuring that yes, yes, he understands. Then back in the studio he continues talking to participants, listens to them although his hair stands up because he knows how the client watching all that from behind the glass will take it. As a psychologist I realise that so many things are beyond my control. Or I can analyse where it's coming from. But really, I just want everyone to be happy. I want the client to be happy, to have him order another project. [Coach and research consultant]

The "field work", which is a completed interview or a series of such interviews, is followed by preparing transcriptions, analyses, a report, and a presentation ${ }^{15}$. In theory, the identity of participants should be protected - companies try to avoid including in their reports (which often consist of excerpts from what respondents said) any data which might hint at the participants' identity; however, this is not always the case ${ }^{16}$. This is crucial because upon handing the results of the research to the client, the researcher loses control over it. For this reason, increasingly more often clients do not receive any so-called "raw data", that is, interview transcriptions or audio and video recordings, even though up to a few years ago such a practice was quite common ${ }^{17}$.

Objectifying participants in marketing research is often explained and justified (also by some researchers) by the fact that they receive payment for their

15 In research companies the entire process takes usually no more than 10 days, and sometimes the researcher is asked to provide a so-called debrief (a short summary and report) right after the interview. The entire research project is usually completed within 3-4 weeks.

16 Along with gradual standardisation of the EU regulations and implementation of the General Data Protection Regulation which came into effect on May 25, 2018, the procedures of processing sensitive data information were elaborated and tightened. In 2017, the research industry established a Quality Control of Information Security Programme and undertook to develop a special GDPR code for the research industry, as mentioned in art. 40 of the GDPR. This project, conducted with the Polish Association of Public Opinion and Marketing Research Firms (Polish acronym: OFBOR) and a law firm, is ongoing (public consultation ended in December 2019).

17 However, records from interviews are still copied and sent outside the company to transcribers who prepare interview transcriptions. 
participation ${ }^{18}$, and that by agreeing to this deal, they consciously "put themselves" in the hands of a research company.

It was selling your soul to the devil, fully coconsciously, with all the consequences. I played that game for money. We were selling our time and involvement. They for a shorter period of time, just for the length of the group discussion. Me of course longer. No one was made to do it. (...) There are no attention paid to relationships. It's just a business contract. Some of those people like it so much that they become professional respondents and could come every day. And I used to be a professional qualitative researcher. [A former researcher who changed her profession, used to work in medium-size companies]

However, such justification does not really seem valid as numerous studies have found that participants do not fully realise what a research process is like [Lisek-Michalska 2013: 232]. Furthermore, as for participants, the interview situation is not only out of the ordinary ${ }^{19}$, but often also something unclear and uncomfortable; they may experience stress and feel threatened [Lisek-Michalska 2013: 233; Mencwel 2013], a feeling which persists throughout the entire study in some participants.

\section{PROBLEMS AND RESEARCH GOALS IN COMMERCIAL RESEARCH}

The ethical dilemmas that researchers face may concern not only the research process itself and the attitude toward human subjects at every stage of this process, but also the very sense and purpose of commissioned research as such. This is especially true for marketing research. Entities participating in the market processes, which order, commission and make use of the results of such studies, do so for their own particular interest - in order to gain an advantage over competitors, that is, to sell the largest possible amount of their products, services and ideas in a way which ensures the largest profit and an opportunity to beat rivals.

And I just keep wondering: What kind of job is it? What is the purpose of it? To convince people to buy even more? To give a package of butter a new look? Who will benefit from it? What for? (...) I think it is quite symptomatic that it is quite difficult to explain to the older generation on the one hand, and to children on the other, what we actually do. My

18 For their participation in a project, participants usually receive renumeration (usually financial, sometimes in the form of prizes). Research companies strive to offer a remuneration adequate to the time participants dedicated to the study, and make it target-specific for a particular group. Therefore, it can be neither too low - because the recruited person will not show up - nor too high, so as to avoid a so-called reciprocation principle, skewing the participant's attitude.

19 One of the basic requirements in commercial research is to select people who either have never participated in such a study before, or at least a year has passed since they participated in it. 
grandmother could never understand it, my mother also does not really know what I do, and when I tried to explain my job to my little niece she asked, But what do you do it for?". And I find it so symbolic... That kids do not know why we do it. Doctors - that is easy - they treat people who are sick. Cashiers and store assistants sell food and other stuff, teachers teach. And I? Why do I do it for? [Director of qualitative research in an international research agency]

Market research is usually thought of as a helpful marketing instrument, which is supposed to recognise and discover consumers' needs so that the products and services offered by companies can better meet and exceed consumers' expectations. It seems, however, that nowadays when the market is so saturated - which makes it increasingly more difficult to invent something truly innovative and unique - the goal of the research (and the goal of the researcher) is quite different.

Thus, the goal is no longer to discern the consumer's "actual" (if subconscious) needs and address them by modifying a given product or service in a way which would make life easier. The new goal is rather to artificially create a consumer need in order to facilitate the introduction of products or services which are only superficially innovative, positioned extremely hermetically, or - to put it bluntly - simply unnecessary and useless. As Anna Giza asks sarcastically in her book "The Wizard's Student - the Social History of Marketing": "What, for example, were to be gained from the biscuit having exactly 52 bumps on the edges?" [Giza 2017: 194].

Qualitative researchers who work in the area of commercial research put it bluntly:

First, I chose a degree in sociology, then I moved to research because I wanted to learn something about human beings, get to know them better. And in reality, I ended up writing reports about packages of dairy products, trying to convince people that the ones in green packages will be even more delicious than those from a year before... [Manager in a qualitative research team]

It is as if we forgot why we do the research in the first place. Nothing counts anymore but the throughput and profit, the human being is out of the equation. [Director of a research boutique]

For years the largest part of research institutes' revenues has come from projects for the FMCS industry [Fast Moving Consumer Goods; Chojnowski 2019: 28] - products which, as evidenced by the name itself - are bought, used and disposed of. Qualitative researchers, who are generally reflective in nature, realise that the constant quest for unnecessary "innovations" will not make people happier, and the knowledge and skills of researchers may be used here in a questionable way. In today's world, which is still dealing with the effects of the last economic crisis and drowning in mountains of waste, it has become much 
more evident that expansive consumerism ${ }^{20}$ - compulsive and excessive buying and collecting items at the cost of debts and loans - does not bring happiness in the long run; rather it becomes a source of constant stress and frustration [cf. Klein 2004, Wallmann 2015: 14].

I had an issue with such research from the very beginning, a problem of a general nature, a very, very basic one (...) After all, our job is to constantly create new needs, and we do it only so that some corporation would sell more and more of their stuff. Don't get me wrong, I didn't work only for corporations, but I did some work for the largest ones too, and every single time I was about to show them my report or presentation I was so torn apart inside. It wasn't my world, yet I participated in it and promoted it so much. [Researcher who having worked in medium-size research companies in the past decided to change her profession.] I had a project for shadow bank loans. In theory it's all legal but... to me it's simply an usury. And the advert I worked on was about a grandfather who took such a loan to buy a present for his grandson. So it's like... if you love your grandkids, you have to keep up with the Joneses. I felt so disgusted with myself. [Researcher working at the client's research department]

Another example of an ethical dilemma in commercial social research is conducting research for clients whose products or services the researcher not only does not connect with, or sees no point in their commercial success on the market, but even actually personally rejects; these could include products considered unhealthy, or even harmful, such as alcohol, tobacco, or "junk" food. It is especially important in research dealing with children's products because children are yet to develop the skills necessary to defend themselves against marketing mechanisms.

One day my 8-year-old son noticed on my desk a presentation for X. 'Mom! We are not allowed to eat it!', Yes, dear, we don't eat it, this is just my work. But what are you doing? You don't allow us to eat it and you say it's bad for us and you want other kids to eat it?' [An experienced manager of a qualitative research team in an international research company; now works in a different profession]

Similar dilemmas may be faced by researchers conducting social-political research for specific groups, political parties or their leaders, whose views run counter to their own. After all, politicians and political parties are constructed according to a very similar principle to products and services brands; as Sennett [2010: 131] puts it, "the marketing of personalities to an increasingly greater degree covers the narration about the politician himself and his accomplishments...", and research in the field of political marketing plays a significant role in this process.

20 To describe this phenomenon, James Wallmann [2015: 14] coined a neologism "stuffocation", which can be translated as "materialistic enslavement" of modern man. 


\section{CONCLUSION}

Is it therefore possible, from the point of view of a researcher working in a research agency conducting commissioned research in Poland to be ethical?

Personally, I am inclined to say it is possible, and numerous such projects have proven so. However, much depends on the character of a given company and the standards it has adopted ${ }^{21}$, as well as the principles adopted in particular departments and research teams. It is significant what kind of professional experience researchers have and what patterns of behaviour they adopt as a standard and reference point (e.g., such patterns may be adopted from more experienced colleagues).

What is further emphasised is the fact that research companies (even the certified ones), teams, and researchers themselves sometimes agree to conditions which are far from optimal so as not to lose a client or to be awarded a project. It is not easy to negotiate this power structure and define clear boundaries, and the price for failing to do so is paid by research participants, the researcher, and the quality of the project.

Does this make the researcher co-responsible? This question cannot be answered by utilising the codes of conduct or any other guidelines of a general nature. All researchers individually may therefore adopt extremely different stands depending upon their own personal moral code and also on their authority/seniority in the work environment which may or may not give them an opportunity to refuse to conduct a study on a certain topic or to work for a given client.

Are then any systemic changes possible? Certainly, there is a necessity for a thorough discussion on the ethics of commissioned research, where the practices in commercial research (including those of a qualitative nature) are analysed and where they will be evaluated in order to verify whether these practices contribute to improvements in the research process and to the well-being of all parties involved. Perhaps as a result we would conclude that observing groups and interviews do more harm than good. Such observations could then be abolished and in the rare instances where it is truly indispensable, the number

${ }^{21}$ It is worth noting that some research agencies belong to the Polish Association of Public Opinion and Marketing Research Firms, an organisation established in 1997 as a union of employers whose goal was to "control the adherence to ethical and methodological norms in market and opinion research, as well as to work towards increasing public trust of research" [OFBOR]. Among their initiatives were the Surveyors' Quality Work Control Programme [Polish acronym PKJPA] and PKJPA certification (a result of the Surveyors' Quality Work Control Programme, promoting quality standards in the realm of field work and providing minimum quality norms when it comes to organising the Executive Department; also in the range of qualitative research). 
of observers could be reduced to the absolute minimum. However, the research agency should ensure that the observers are trained in collecting data in qualitative research and are aware of the nature of the research process. Thus, perhaps we should adopt a new standard - an additional qualitative researcher ${ }^{22}$ present in the viewing facility. Their task would be to co-coordinate the project and explain any doubts the observers might have as they arise. The moderator would not be contacted unless absolutely necessary. Not only would it make the work of the researcher far more comfortable, but it might well contribute to the well-being of the respondents as well.

More consideration should also be given to the recruitment process itself - to provide an appropriate room and allocate enough time to explain any doubts participants may have so that their consent to participate in the project is truly informed, which would be benefitable for the quality of the study itself.

The aforementioned suggestions are justified, but at the same time utopian. Qualitative research is less profitable ${ }^{23}$ and therefore it is often treated as an inferior category of research, in particular in larger companies. Reducing its profitability and attractiveness to the client even more, in times when everyone is looking for savings would be unlikely to spark enthusiasm among decision makers, and as such is probably not going to happen. Particularly as research agencies often perceive visits the clients make during interviews as a chance to bond with them (also on the social level) to boost orders for other, more profitable studies.

Nevertheless, such changes and practices, if presented and explained well to clients, can be implemented in smaller agencies, so-called "qualitative boutiques", appropriately positioned and dedicated primarily to qualitative research. Such boutiques are currently on the increase; they are usually established by experienced researchers who have their loyal and committed clients, although they are often too small to be noted in official statistics describing the market of research agencies.

An in-depth explanation of the nature of the qualitative methodology and principles of fieldwork, both to clients and participants alike, could also prove beneficial. Another recommendation worthy of consideration would be regular meetings of a "supervisory" nature where researchers could explain or at least verbalise any doubts, dilemmas or emotions they experience in their work. However,

${ }^{22}$ Some companies known to me are extremely serious about it, however in such instances the costs of the project become higher.

23 According to PTBRiO, in 2018 the revenue from qualitative research constituted only $10 \%$ of the revenue of research agencies -64 million PLN (to the total of 715 million PLN) [Chojnowski 2019: 29]. 
to the best of my knowledge, research companies do not provide training sessions or workshops focused on research ethics or fieldwork. Neither do they provide any "supervision" of researchers ${ }^{24}$. The commercial research environment, or at least the decision makers, do not seem to show much interest in such solutions. Among various courses and workshops offered by the Polish Society of Market and Opinion Researchers (PTBRiO) there is not a single one on this topic ${ }^{25}$.

The ethical dilemmas and problematic situations certainly cannot be eliminated, not least because incursion into the lives of other people (which any social research by its very nature necessarily is) will forever remain debatable. However, what we can and should do is continue the debate on these dilemmas and problematic situations in a forthright manner.

\section{BIBLIOGRAPHY}

American Anthropological Association. 2012. Statement on ethics: Principles of professional responsibility. http://ethics.aaanet.org [access: 14.05.2020].

Association of Social Anthropologists of the UK and the Commonwealth. 2011. Ethical guidelines for good research practice. http://www.theasa.org [access: 14.05.2020].

Archanowicz-Kudelska Katarzyna. 2017. Badacze rynku i opinii. Role zawodowe, biografie, wyzwania. Unpublished doctoral dissertation. SWPS Uniwersytet Humanistycznospołeczny Warszawa.

Babbie Earl. 2006. Badania społeczne w praktyce, trans. W. Betkiewicz, M. Bucholc, P. Gadomski. Warszawa: Wydawnictwo Naukowe PWN.

Charmaz Kathy. 2009. Teoria ugruntowana. Praktyczny przewodnik po analizie jakościowej, trans. B. Komorowska. Warszawa: Wydawnictwo Naukowe PWN.

Chojnowski Piotr. 2019. Rynek badań w Polsce w 2018 roku. In: Badania Marketingowe. Rocznik Polskiego Towarzystwa Badaczy Rynku i Opinii. Edycja XXIV-2019/20, A. Wódkowski (ed.), 28-29. Warszawa: PTBRiO.

Corbin Juliet. 2009. Taking an analytic journey In: Developing grounded theory: The second generation, J.M. Morse, B. Bowers, P.N. Stern, J. Corbin, K. Charmaz, A.E. Clarke (eds.), 35-54. Walnut Creek: Left Coast Press.

Dickson-Swift Virginia, Erica L. James, Sandra Kippen, Pranee Liamputtong. 2007. "Doing sensitive research: What challenges do qualitative researchers face?". Qualitative Research 7: $327-353$.

Dudkiewicz Magdalena. 2016. „Dylematy etyczne badań prowadzonych na zlecenie instytucji publicznych - doświadczenia badacza terenowego". Przeglad Socjologii Jakościowej 12(3): 136-147. http://www.qualitativesociologyreview.org/PL/Volume35/PSJ_12_3_Dudkiewicz. pdf [access: 17.04.2018].

24 There were none of such practices at the time when I was conducting the interviews.

25 They can be found on the academic market; among their participants we also find business people who out of their own needs and often investing their own resources sign up for such courses. 
Hammersley Martyn, Paul Atkinson. 2000. Metody badań terenowych, trans. S. Dymczyk. Poznań: Wydawnictwo Zysk i S-ka.

Giza Anna. 2017. Uczeń czarnoksiężnika, czyli społeczna historia marketingu. Warszawa: Wydawnictwa Uniwersytetu Warszawskiego.

ICC/ESOMAR. 2016. International code on market, opinion and social research and data analytics. https://www.esomar.org/uploads/pdf/professional-standards/ICCESOMAR_Code_English_pdf [access: 05.02.2020].

Konecki Krzysztof. 2000. Studia z metodologii badań jakościowych. Teoria ugruntowana. Warszawa: Wydawnictwo Naukowe PWN.

Klein Naomi. 2004. No logo, trans. H. Pustuła. Izabelin: Świat Literacki.

Kvale Stainar. 2004. InterViews. Wprowadzenie do jakościowego wywiadu badawczego, trans. S. Zabielski. Białystok: Trans Humana.

Kvale Stainar. 2010. Prowadzenie wywiadów, trans. A. Dziuban. Warszawa: Wydawnictwo Naukowe PWN.

Lisek-Michalska Jolanta. 2013. Badania fokusowe. Problemy metodologiczne i etyczne. Łódź: Wydawnictwo Uniwersytetu Łódzkiego.

Maison Dominika. 2010. Jakościowe metody badań marketingowych. Jak zrozumieć konsumen$t a$. Warszawa: Wydawnictwo Naukowe PWN.

Maison Dominika. 2015. Nowe podejście do badań jakościowych jako konsekwencje zmian w rozumieniu zachowań konsumenta. In: Badania marketingowe. Praktyka nauce - nauka praktyce, A. Dąbrowska, A. Wódkowski (eds.), 9-31. Warszawa: Instytut Badań Rynku Konsumpcji i Koniunktura.

Marciniak Beata. 2014. „Motywacje i postawy wobec stosowania systemów normatywnych regulujących sferę badań marketingowych - doniesienie z badań empirycznych". Prace Naukowe Uniwersytetu Ekonomicznego we Wrocławiu 337: 281-291.

Mencwel Stanisław. 2013. Po drugiej stronie lustra, czyli badani o badaniach. Referat wygłoszony na XIV Kongresie Badaczy Rynku i Opinii, Warszawa.

Niedbalski Jakub. 2016. „Dylematy etyczne i problemy metodologiczne warsztatu badacza na przykładzie badań prowadzonych w środowisku osób z niepełnosprawnością intelektualną oraz niepełnosprawnością fizyczną". Studia Humanistyczne AGH 15(4): 35-51.

OFBOR. nd. Organizacja Firm Badania Rynku i Opinii. https://www.ofbor.pl/index.php/organizacja-2 [access: 09.02.2020].

Poleszczuk Jan. 2009. Publiczny status i wartość poznawcza badań społecznych. In: Metody, techniki i praktyka badań społecznych, A. Bąk, Ł. Kubisz-Muła (eds.), 11-21. Bielsko-Biała: Akademia Techniczno-Humanistyczna w Bielsku-Białej. Katedra Socjologii.

Polish Psychological Association. 1991. The code of professional ethics (Kodeks etyczno-zawodowy psychologa). Warszawa: Polskie Towarzystwo Psychologiczne.

Polish Sociological Association. 2012. The sociologist's code of ethics. (Kodeks etyki socjologa) http://pts.org.pl/wp-content/uploads/2016/04/kodeks.pdf [access: 02.12.2018].

Przybylowska Ilona. 1975. Wywiad o wywiadzie jako metoda otrzymywania informacji o reakcji wewnętrznej respondenta na pytanie kwestionariusza. In: Analizy i próby technik badawczych w socjologii. Studia pilotażowe i analizy weryfikacyjne (vol. 5), Z. Gostkowski, J. Lutyński (eds.), 457-488. Wrocław-Warszawa-Kraków-Gdańsk: Ossolineum.

Przybyłowska Ilona. 1978. „Wywiad swobodny ze standaryzowaną listą poszukiwanych informacji i możliwości jego zastosowania w badaniach socjologicznych”. Przegląd Socjologiczny 30: 53-68. 
RODO w branży badawczej. http://rodowbranzybadawczej.pl [access: 22.012020 ].

Sennett Richard. 2010. Kultura nowego kapitalizmu, trans. G. Brzozowski, K. Osłowski. Warszawa: Muza S.A.

Sielicki Janusz, Wojciech Ciemniewski. 2013. Badanie badaczy - raport. Warszawa: Polskie Towarzystwo Badaczy Rynku i Opinii.

Staszyńska Katarzyna. 2013. Marka, konsument, badacz, Spotkania na rynku. Warszawa: Wolters, Kluwer, Polska SA.

Surmiak Adrianna. 2016. „Wybrane problem etyczne w naukowych badaniach na zlecenie. Refleksje etnografki”. Przegląd Socjologii Jakościowej 12(3): 120-134. http://www.qualitativesociologyreview.org/PL/Volume35/PSJ_12_3_Surmiak.pdf.

Ślęzak Izabela. 2016. Praca kobiet świadczących ustugi seksualne $w$ agencjach towarzyskich. Łódź: Wydawnictwo Uniwersytetu Łódzkiego.

Ślęzak Izabela. 2018. „Praca nad zaufaniem. Etyczne, praktyczne i metodologiczne wyzwania w relacjach badacz-badani na przykładzie etnografii agencji towarzyskich". Przeglad Socjologii Jakościowej 14(1): 138-162. DOI: http://dx.doi.org/10.18778/1733-8069.14.1.07 [access: 12.05.2019].

Świątek-Młynarska Paulina. 2019. „Problemy etyczne w relacji badacza z osobami badanymi (na przykładzie badań biograficznych z osobami starymi)". Przegląd Socjologii Jakościowej 15(4): 204-223. DOI: http://dx.doi.org/10.18778/1733-8069.15.4.10 [access: 12.01.2020].

The code of academic ethics (Kodeks etyki pracownika naukowego). 2012. http://www.nauka. gov.p1/g2/oryginal/2014_02/2ae2188ff8670eed98ede50de1e9007f.pdf [access: 04.12.2018].

Urbaniak-Zając Danuta, Ewa Kos. 2013. Badania jakościowe w pedagogice: Wywiad narracyjny i obiektywna hermeneutyka. Warszawa: Wydawnictwo Naukowe PWN.

Wallmann James. 2015. Stuffocation. Living more with less. London-New York, Penguin Group.

Katarzyna Archanowicz-Kudelska

\section{ETYKA W KOMERCYJNYCH BADANIACH JAKOŚCIOWYCH - KTOKOLWIEK WIDZIAL, KTOKOLWIEK WIE? O DYLEMATACH ETYCZNYCH BADACZY PRACUJĄCYCH NA ZLECENIE}

Streszczenie

Celem artykułu jest refleksja nad problemami natury etycznej, przed którymi staje badacz, stosujący w swojej pracy metodologię jakościową, a pracujący w badaniach, w których zewnętrzny podmiot jest zleceniodawca, ewaluatorem i odbiorcą badań, a zatem może wywierać wpływ na przebieg procesu badawczego. Z taką sytuacją mamy do czynienia w przypadku badań komercyjnych - badań społecznych i politycznych czy badań rynku i opinii. W artykule, posiłkując się literaturą przedmiotu, przedstawię zarówno analizy przeprowadzone do projektu na temat przebiegu karier zawodowych komercyjnych badaczy rynku i opinii, na którym oparłam pracę doktorską, jak przykłady z własnej wieloletniej praktyki badawczej. Mam nadzieję, że staną się one przyczynkiem do dalszej dyskusji na ten temat.

Słowa kluczowe: etyka badań, badania jakościowe, badania na zlecenie, badania komercyjne 